\title{
RURAL STUDENTS' CONCEPTUAL UNDERSTANDING OF DIFFUSION AND OSMOSIS
}

\author{
Irene Lue Leh Ping ${ }^{1 *}$, Lilia Halim² and Kamisah Osman ${ }^{3}$ \\ ${ }^{1,3}$ Department of Teaching and Learning Innovation, Faculty of Education, \\ Universiti Kebangsaan Malaysia, 43600 UKM Bangi, Selangor, Malaysia \\ ${ }^{2}$ Department of Education Policy and Leadership, Faculty of Education, \\ Universiti Kebangsaan Malaysia, 43600 UKM Bangi, Selangor, Malaysia \\ *Corresponding author: P88705@siswa.ukm.edu.my
}

Publication date: 30 June 2020

To cite this article: Irene Lue Leh Ping, Lilia Halim, \& Kamisah Osman. (2020). Rural school students' conceptual understanding of diffusion and osmosis. Asia Pacific Journal of Educators and Education, 35(1), 93-109. https://doi.org/10.21315/apjee2020.35.1.6

To link to this article: https://doi.org/10.21315/apjee2020.35.1.6

\begin{abstract}
The purpose of this study was to determine students' understanding of the topic "Movement of Substances Across the Plasma Membrane" that covers the concepts of diffusion and osmosis. This study adopted the survey research design. A total of 288 students studying in Grade 10 in rural secondary schools were assessed. The instrument used is a test called the Movement of Substances across the Plasma Membrane (MSPM) is a two-tier multiple-choice question test with a high reliability coefficient $(r=0.877)$. The results show that the majority of students, i.e. $54 \%$ of the students obtained average scores. The findings reveal that the overall performance of the students in terms of their understanding of the concepts of diffusion and osmosis was unsatisfactory. An implication of the study is that the MSPM test (two-tier diagnostic test) provides a feasible approach for evaluating students' understanding and for identifying students' coherent understanding of the diffusion and osmosis concepts. It was found that even though students chose the correct option at the first tier of the test, but it was revealed that students provided misconceptions when had to give explanations to their options in the first tier. The misconceptions identified in the study could serve as a resource for Biology teachers to promote meaningful learning.
\end{abstract}

Keywords: Diffusion, osmosis, secondary, Biology, rural school 


\section{INTRODUCTION}

The concepts of osmosis and diffusion are vital to understanding of the nature of organisms and how they function. Furthermore, the concepts of diffusion, semi permeability, and osmosis are fundamental to mastering many topics in Chemistry, Physics and Biology (Hasni, Roy, \& Dumais, 2016; Odom, Barrow, \& Romine, 2017; Tomažič \& Vidic, 2012). Yet, these have also proven to be among the most difficult concepts for students to understand. Eventually, students have inadequate conceptions or major difficulties in understanding these phenomena. Ultimately, having adequate or inadequate conceptions in diffusion and osmosis can affect students' performance or the tasks undertaken in other science-related learning (Malińska, Rybska, Sobieszczuk-Nowicka, \& Adamiec, 2016; Oztas, 2014; Torkar, Veldin, Glažar, \& Podlesek, 2018).

With satisfactory understanding of the concepts of diffusion and osmosis, students can make favourable comments about their own metabolism and the events which exist in nature (Artun \& Coştu, 2011). In addition, with adequate understanding of osmosis, students can understand water intake, water balance in plants and animals and other more physical concepts such as turgor pressures and transport in living organisms (AlHarbi, Treagust, Chandrasegaran, \& Won, 2015). If students can understand the forces that lead to these phenomena and the resulting consequences, they will have an easier time understanding more advanced topics. Unfortunately, many teachers do not spend much instructional time on these concepts (Hasni et al., 2016; Patel, 2012; National Research Council, 2006) or challenge students' misconceptions of these concepts (Odom et al., 2017; Tekkaya, 2003). Thus, students leave their classes with only basic understanding of these fundamental concepts in their learning (Fisher, Williams, \& Lineback, 2011; Malińska et al., 2016).

\section{LITERATURE REVIEW}

\section{Students' Misconceptions and Alternative Conceptions in Diffusion and Osmosis}

Learning and achieving deep understanding of many science concepts are extremely difficult for middle and high school students. Thus, when students lack depth of understanding, they either repeat incorrectly, learn partially, or forget (Stern, Ferraro, \& Mohnkern, 2017) and lack of understanding is displayed in their naive explanation (Chi, 2009). According to Chi (2009), students' naive explanations are often called misconceptions while Caleon and Subramaniam (2010) use 
alternative conceptions (ACs) to refer to modifications of conceptions that differ from established scientific knowledge. Taber (2011) explains that misconceptions are inappropriate for those situations where an individual acquires incorrect ideas technically, and that a more suitable term to use would be alternative conceptions as the learners do not 'misconceive' what has been taught but rather may correctly understand the alternative conceptions presented. For the purpose of this study, the term 'misconception' is used to describe inaccurate or incorrect understanding of scientific concepts while 'alternative conceptions' is used to describe partial understanding of scientific concepts.

Learning about diffusion and osmosis is often a challenging task for students (Sweeney \& Martin-hansen, 2009). Studies have shown inconsistent results in the understanding of both processes, and both processes are often difficult for students to understand (Cinici, Sozbilir, \& Demir, 2011). These, however, are contrary to the findings of some research that report diffusion and osmosis as topics that are the least difficult to learn (Çimer, 2012; Mispuah \& Kamisah, 2016). Notwithstanding, studies continue to show that students' understanding of these two concepts is still unsatisfactory (Fisher et al., 2011; Oztas, 2014; Oztas \& Oztas, 2016). Thus, it could be argued that Oztas' (2014) suggestion that diffusion and osmosis are simple concepts because they are so basic is inaccurate. In sum, it is observed that studies which investigate students' understanding of these two concepts have included almost all levels of education including secondary school Biology students. Nonetheless, based on literature review, it is apparent that there is very limited research investigating rural secondary school Biology students' understanding of the concepts of diffusion and osmosis.

In the Malaysian context, diffusion and osmosis are taught in Grade 10 Biology lessons (Curriculum Development Centre, 2006, 2018). Specifically, diffusion and osmosis are integrated in teaching the topic on Movement of Substances Across the Plasma Membrane (MSPM). Studies involving these two concepts both directly (Gill, 2005; Lee \& Daniel, 2012; Maimunah, 2005) and indirectly (Lee, 2013) have reported that the students' coherent understanding of the whole concept of diffusion and osmosis in the cell is still weak. As suggested by Lee and Daniel (2012), there is a need to have more field tests to delve deeper into students' understandings of the cell and movement of substance across the plasma membrane as a whole. Furthermore, the coherency test when compared to the diffusion and osmosis diagnostic test (DODT) (Odom, 1995) is more suitable for the Malaysian context as it is specifically tailored to the Malaysian Secondary School Biology Curriculum. Ultimately by look into the achievement of students in rural school environment with respect to the concepts of diffusion and osmosis, educators can effectively design relevant instructional opportunities. Therefore this present study 
focused on assessing secondary school students' coherent understanding of the MSPM topic in connection to the concepts of diffusion and osmosis through the use of a two-tier diagnostic test in rural school environment. This present study sought to answer the following research questions:

a. What is the overall understanding of the MSPM topic among the rural secondary school Biology students?

b. What are the misconceptions held by the rural secondary school Biology students on the MSPM topic?

\section{METHODOLOGY}

This study employed the survey research design in which a two-tier diagnostic test was used to assess rural secondary school students' coherent understanding of MSPM which is a topic in Grade 10 Biology subject. The survey research method would allow the researcher to obtain first-hand information regarding the rural students' level of coherent understanding of the MSPM topic.

The population of the study comprised science students taking Biology subject in secondary schools. The study involved Grade 10 students specifically because the students have completed the Grade 10 (age 16 years) syllabus which covered the Biology topic MSPM. The students were given 30 minutes to complete the test. The research sample was 288 students who were proportionally drawn from 11 secondary schools in District A in Sarawak, a state in East Malaysia. The samples were chosen using purposive sampling technique. The technique was used to ensure that the sample has the attributes relevant to the purpose of the study namely students from rural schools. The schools were selected from a list of rural schools provided by the State Education Department. The schools involved in the study were strictly those that offered science stream, particularly Biology at the upper secondary school level.

The research instrument used in this study was the MSPM test. The instrument, originally developed by Lee and Daniel (2012) and Odom (1995), was modified by the researcher to suit the purpose of this present study. A test blueprint which is also known as the table of specifications was used to construct the MSPM test to ensure that the test samples all important content areas and processes which include different levels of cognitive complexity. The distribution of items and coherency among the topic areas along with the cognitive dimension of Bloom's taxonomy (revised) are specified in Table 1. 
Each item on the MSPM test has two tiers. As shown in Table 1 (Table of specification), the instrument consists of 40 objective test items. It is designed to include two options which are lettered A-B or three options which are lettered A-C or four options lettered A-D, out of which only one is the correct acceptable answer based on all the learning outcomes in the subject of Biology identified in the Malaysian Secondary School Biology Curriculum. The first tier consists of a content question with two, three or four answer choices. The second tier consists of four possible reasons for the content questions in the first tier: three alternative reasons and one scientifically accepted reason. Figure 1 shows a sample item from the MSPM test that assesses the topic area of Passive Transport.

The MPSM test went through a validation process which was carried out by a panel of expert. The panel consisted of two Science education lecturers and a Biology subject expert. The validation included inspection of the test by the experts where they were asked to go through the questions and to circle questions which were not clear and had grammatical errors in them. Next, the experts were asked to provide their feedback and reviews on the items assessed in the test. Prior to carrying out the validation, the experts were provided with the learning outcomes together with a brief outline of each item to provide them with information on the contents of each item and to gain their feedback on these items.

The results of the analysis show that the agreement obtained between the experts in relation to content validity for the test was $r=0.93$ (Johnson \& Christense, 2017). The validated MSPM test was then piloted with a group of 32 rural secondary school students similar to the target group. The test's reliability was calculated using the Kuder-Richardson formula 20 (KR20). The Cronbach's Alpha value was $\alpha=0.877$. According to Lodico, Spaulding and Voegtle (2010), correlation coefficients ranging from 0.84 or higher indicate very strong reliability. Thus, the Cronbach's Alpha obtained assured that the MSPM test has very high reliability in internal consistency.

The researcher visited the rural secondary schools within district $\mathrm{A}$ and administered the diagnostic tests to Grade 10 Biology students in these schools. The students were instructed to attempt all the question items to the best of their knowledge in 30 minutes under the supervision of the teachers in charge and the researcher herself. Copies of the test were immediately collected by the researcher after the test period of 30 minutes was over. 
Table 1. Table of specification for the MSPM test

\begin{tabular}{llc}
\hline Coherency of the topic areas & \multicolumn{2}{c}{ Cognitive dimension } \\
\hline $\begin{array}{l}\text { Topic Area 1: Structure and properties of plasma } \\
\text { membrane with cell component and types of movement } \\
\text { (passive and active transport) (Refer to Lee and Daniel, }\end{array}$ & Remember & 1,2 \\
2012) & Application & $3,4,7$ \\
Topic Area 2: Passive transport (Refer to Odom, 1995) & Application & 5,6 \\
& Remember & 9,10 \\
$\begin{array}{l}\text { Topic Area 3: Hypotonic, hypertonic and isotonic } \\
\text { solutions and passive transport (Refer to Odom, 1995) }\end{array}$ & Application & 11,12 \\
$\begin{array}{l}\text { Topic Area 4: Effects of hypotonic, hypertonic and } \\
\text { isotonic solutions in plant cells or/and animal cells (Refer }\end{array}$ & Evaluate & 13 \\
to Lee and Daniel, 2012) & Analyse & $14,16,17$ \\
$\begin{array}{l}\text { Topic Area 5: Structure and properties of plasma } \\
\text { membrane with type of substances and movement } \\
\text { (passive and active transport) (Refer to Lee and Daniel, }\end{array}$ & Application & 15 \\
2012) & Evaluate & 18 \\
\hline
\end{tabular}

10a. As the difference in concentration between two areas increases, the rate of diffusion: Apabila perbezaan kepekatan bagi dua kawasan meningkat, kadar resapan:

A. decreases menurun

B. increases meningkat

10b. The reason for my answer:

A. The molecules want to spread out. Molekul akan tersebar.

B. There is less space for the particles to move. Terdapat kekurangan ruang bagi zarah-zarah bergerak.

There is a greater likelihood of random motion in to other regions. Kemungkinan pergerakan rawak zarah-zarah ke dalam kawasan lain adalah lebih besar.

D. If the concentration is high enough, the particles will spread less and the rate will be slowed.

Jika kepekatan adalah cukup tinggi, zarah-zarah akan kurang tersebar dan kadar resapan akan menjadi lambat.

Figure 1. Sample item in the MSPM test that assesses the topic area of passive transport

In scoring the MSPM test, marks are awarded based on the concepts examined in the topic of diffusion and osmosis. A maximum score of 40 is awarded to the total of 20 two-tier multiple-choice items. Specifically, a score of two points is given to an item when both the correct answer and reason are selected. A score of 
one point is given to an item when the correct answer (first-tier item) is selected but the incorrect reason (second-tier item) is chosen. No point is awarded to an item when the incorrect answer (first-tier item) is selected. Table 2 summarises the MSPM test scoring. When a student answers both items (first and secondtier items) correctly, the student is said to have coherent scientific understanding. However, when a student answers only the first-tier item correctly but fails to give the correct reason (second-tier item), the student is said to have an alternative understanding (partial scientific understanding) of the concept. In contrast, if a student is not able to answer the first level question (first-tier item) correctly and either answer correctly or failed to give the correct second-tier item, the student is said to have misconception (the wrong scientific understanding) of the concept.

Table 2. Summary of MSPM's scoring

\begin{tabular}{lcccc}
\hline First tier & Second tier & $\begin{array}{c}\text { Score } \\
\text { allocated }\end{array}$ & \multicolumn{2}{c}{ Interpretation } \\
\hline $\begin{array}{l}\text { 1a to 20a } \\
\text { Correct }\end{array}$ & $\begin{array}{c}\text { b to } 20 \mathrm{~b} \\
\text { Correct }\end{array}$ & 2 & $\begin{array}{c}\text { Correct scientific } \\
\text { understanding }\end{array}$ & Scientific understanding \\
Correct & Wrong & 1 & Partial scientific understanding & Alternative conception \\
Wrong & Correct & 0 & $\begin{array}{c}\text { Inaccurate scientific } \\
\text { understanding }\end{array}$ & Misconception \\
\hline
\end{tabular}

Each student's score was calculated to determine their level of score based on the range of scores assigned. The summary of the scoring categorisation for the student's score in the MSPM test is displayed in Table 3.

Table 3. Summary of MSPM's scoring categorisation according to the level of score

\begin{tabular}{lcc}
\hline & Range of scores & Level of score \\
\hline 1 & $80-100$ & High \\
2 & $41-79$ & Average \\
3 & $0-40$ & Low \\
\hline
\end{tabular}

Based on Table 3, 0-40 is categorised as low score, 41-79 is categorised as average score and $80-100$ is categorised as high score. 


\section{RESULTS AND DISCUSSION}

\section{What Is the Overall Understanding of the MSPM Topic among the Rural Secondary School Biology Students?}

The students' scores in the MSPM test where the mean (average) was $43.57 \%$ with the standard deviation of the students' scores was 19.04 and approximately half of the students $(49.7 \%)$ were below the mean scores. It can be inferred that the students' overall understanding of the MSPM topic is average only. This result further to be supported by the level of score (Figure 2).

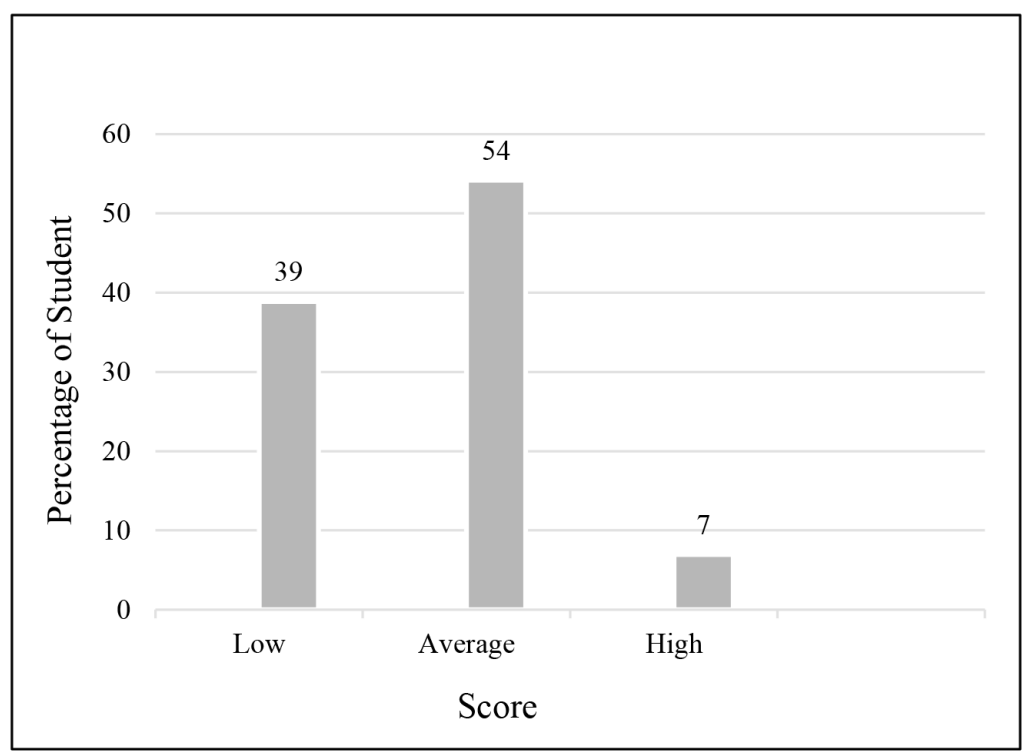

Figure 2. Bar chart illustrating the distribution of students' score in the MSPM test

Figure 2 presents the percentage of students who scored low, average and high level of score in the diagnostic test. Based on the results presented, it can be inferred that the students' overall understanding of the MSPM topic is average. This is because the interval score (40-79) accounted for the highest frequency count of 156 students which is equivalent to $54 \%$ of the total number of students $(n=288)$ assessed in this study. The results also show that 112 students, which is equivalent to $39 \%$ of the total students, scored below the minimum pass mark, i.e. $40 \%$ while only 20 students or equivalent to $7 \%$ of the total number of students scored above 80 , obtaining an grade $\mathrm{A}$ for the test. 


\section{What Are the Misconceptions Held by the Rural Secondary School Biology Students on the MSPM Topic?}

Table 4 shows the students' misconceptions (Not able to answer the first-tier item correctly and either answer correctly or failed to give the correct second-tier item), alternative conceptions (Able to answer the first-tier item correctly but fails to give the correct second-tier item) and scientific knowledge understanding (Able to answer the both first and second-tier items correctly) in detected in the five topic areas.

Looking at Topic Area 1 (Plasma membrane, cell component, types of movement), Table 4 shows that more than $50 \%$ of the students have misconceptions for Items 2, 4, 5, 6 and 7 and this might indicate that the students learnt about the structure of plasma membranes separately from the components of plasma membrane and types of movement. Thus, students failed to apply (Items 4, 7) or evaluate (Items 5,6) even remember (Item 2) the right choice in the first level question. For Items 8-10 (Topic Area 2 - Passive transport), 54.9\% and $42.3 \%$ of students have scientific knowledge understanding of passive transport for Item 8 and Item 10, respectively. But more than $50 \%$ of the students have alternative conceptions about the passive transport on item 9 whose failed to provide the right reason to support their choice in the first level question. This might indicate that students' understanding related to the concept of particles and random movements of particles in high concentration areas moving to other areas remains inadequate.

Meanwhile, the findings in Table 4 also shows that for Items 11-13 (Topic Area 3 Tonicity and passive transport), more than $40 \%$ of the students have misconceptions and this shows that majority students failed to apply (Items 11,12) and evaluate (Item 13) the right choice in the first level question which related to the concept of osmosis in terms of the movement of water (solvent) from hypotonic, hypertonic and isotonic solution across semi-permeable membranes. For Items 14-18 (Topic Area 4 - Effect of tonicity on living organisms), more than $50 \%$ of the students have scientific knowledge understanding for Items 14, 16 and 18 and this indicate that students able to analyse (Items 14, 16) and apply (Item 18) the right reason to support their choice in the first level question. In relation to Item $17,26.7 \%$ of the students have misconceptions, $34.4 \%$ of the students have alternative conceptions and $38.9 \%$ of the students have scientific knowledge understanding of the effects of hypotonic, hypertonic and isotonic solutions in plant cells and animal cells. But more than $50 \%$ of the students have a on passive transport whose failed to remember (Item 15) the right choice in the first level question. This might indicate that students' understanding related to the concept of diffusion and osmosis in life involving the passive transport process in living organisms still unsatisfactory. 
Table 4. Summary of students' misconceptions, alternative conceptions and scientific knowledge understanding detected in the five topic area (indicated in percentage of students

\begin{tabular}{|c|c|c|c|c|}
\hline Topic area & Items & Misconceptions & Alternative conceptions & $\begin{array}{l}\text { Scientific knowledge } \\
\text { understanding }\end{array}$ \\
\hline \multirow[t]{7}{*}{1} & 1 & 11.5 & 67.4 & 21.1 \\
\hline & 2 & 52.1 & 10.8 & 37.1 \\
\hline & 3 & 42.4 & 17.7 & 39.9 \\
\hline & 4 & 55.9 & 8.3 & 35.8 \\
\hline & 5 & 60.8 & 5.9 & 33.3 \\
\hline & 6 & 59.7 & 6.6 & 33.7 \\
\hline & 7 & 70.5 & 3.1 & 26.4 \\
\hline \multirow[t]{3}{*}{2} & 8 & 21.5 & 23.6 & 54.9 \\
\hline & 9 & 21.2 & 51.0 & 27.8 \\
\hline & 10 & 34.4 & 23.3 & 42.3 \\
\hline \multirow[t]{3}{*}{3} & 11 & 43.0 & 11.5 & 45.5 \\
\hline & 12 & 49.0 & 22.9 & 28.1 \\
\hline & 13 & 62.5 & 5.6 & 31.9 \\
\hline \multirow[t]{5}{*}{4} & 14 & 17.4 & 19.1 & 63.5 \\
\hline & 15 & 68.1 & 8.7 & 23.2 \\
\hline & 16 & 28.5 & 20.1 & 51.4 \\
\hline & 17 & 26.7 & 34.4 & 38.9 \\
\hline & 18 & 29.2 & 15.3 & 55.5 \\
\hline \multirow[t]{2}{*}{5} & 19 & 81.6 & 12.8 & 5.6 \\
\hline & 20 & 41.2 & 13.8 & 45.0 \\
\hline
\end{tabular}

Lastly, for Items 19-20 (Topic Area 5 - Plasma membrane, types of substances, types of movement), the findings indicate that more than $40 \%$ of the students have misconceptions for two items and this shows that majority students failed to analyse (Item 20) and evaluate (Item 19) the right choice in the first level question which related to the concept of plasma membrane structure, types of materials, plasma membrane properties, types of movement (passive transport and active) and comparisons between active and passive transport. This might indicate that the students learnt about the respective concepts separately and students' understandings of the cell and movement of substance across the plasma membrane not as a whole. 


\section{Overall Understanding of the MSPM Topic Among the Rural Secondary School Biology Students}

The findings in this study imply that overall, rural secondary school students' understanding of the MSPM topic is not satisfactory because the students' scientific knowledge understanding the MSPM topic is inadequate as their scientific knowledge understanding ranged between $5.6 \%$ to $63.5 \%$ which is less than 70\% (Oztas, 2014; Oztas \& Oztas, 2016). The findings of this present study are in agreement with the findings of previous studies by Fisher, Williams and Lineback (2011), Odom (1995), Zuckerman (1994), Friedler, Amir and Tamir (1987) and Marek (1986) where these previous studies have shown that secondary school students' mastery regarding the concepts of diffusion and osmosis has remained elusive. Additionally, Lee and Daniel (2012) also obtained incoherencies in their study among West Malaysian Biology students where the students in their study scored lower than $50 \%$ in the test they administered. The results obtained in the present study appear to indicate that teaching of Biology in schools may be focusing too much on the acquisition of facts rather than developing students' understanding of the concepts of diffusion and osmosis. As a result, students show misconceptions and alternative conceptions of the concepts and fail to understand the scientific concepts. Hence, these concepts clearly need to be learnt and taught well in schools to help students attain mastery of these scientific concepts.

\section{The Misconceptions Held by the Rural Secondary School Biology Students on the MSPM Topic}

The findings in the present study indicate that the rural school students failed to master scientific knowledge understanding of solute properties, and the types of soluble and protein necessary to transport soluble substances. Two-thirds of the students failed to relate the characteristics of dissolved substances to the type of movement even though they have already learnt that certain soluble substances can transmit plasma membranes through passive transport and active transport in their school syllabus. This alternative understanding has also been identified to occur among urban school students in Lee and Daniel's (2012) study. The finding in the present study shows that most students understand the concept of diffusion. However, approximately two-fifths of the students still have alternative conceptions that particles stop moving in an isotonic solution. This shows that the students have alternative understanding of the movement of particles during isotonic condition regarding to the Topic Area 2. This finding is consistent with previous research such as the ones by AlHarbi et al. (2015) and Artun and Coştu (2011; 2013) where this alternative conception may be caused by the students misinterpreting the term "isotonic". 
Additionally, the findings also show that students have confusion about hypertonic and hypotonic solutions in Topic Area 4. Students in this study could not distinguish the meaning of hypertonic and hypotonic solutions well. This finding is consistent with previous research by Oztas (2014) and Odom and Barrow (2007) in which they argued that the concept of tonicity should not be introduced to high school Biology students until effective instructional approaches can be identified. Although the students have problems in mastering understanding of scientific knowledge concerning the properties of particle-soluble substances across the plasma membrane and the movement of the particles in Topic Area 1, the students showed inconsistent understanding of scientific knowledge regarding the effects of hypotonic, hypertonic and isotonic solutions in living organisms (Topic Area 4) which were tested in the MSPM test. The results provide evidence of rural secondary school students' inadequate or lack of proper mastery of the term plasmolysis and deplasmolysis. Lee and Daniel (2012) have also demonstrated in their study that even urban students have misconceptions concerning concentration and tonicity. Additionally, the findings of this present study also indicate that most of the students were not aware that water molecules can transmit plasma membranes through assisted diffusion in Topic Area 1. The rural students in this study failed to match the type of movement with the correct type of protein involved in Topic Area 5. The majority of the students believed that water movement does not require transport proteins to transmit plasma membranes. This is equivalent to the question in Item 4 in Topic Area 1 where the majority of the students were not aware that water molecules need a carrier protein as well.

The findings of this present study are further supported by the report on the quality of students' answers in the 2012 SPM Biology paper (Lembaga Peperiksaan Malaysia (LPM), 2014) where the report highlighted that students did not seem to understand the terms flaccid, plasmolysis, turgid, shrinkage, haemolysis and crenation. In addition, the students' answers also showed their complete lack of understanding of the term isotonic in tonicity and students assumed that isotonic drinks can refresh or energise the body. Students were also unable to correctly compare the different concentrations of the solutions. LPM reported that students showed understanding of the concept of osmosis but were unable to compare the concentration between two different solutions or three different solutions (hypotonic, isotonic and hypertonic solutions). Most students even described hypotonic, isotonic and hypertonic as cell conditions. In addition, students were not able to answer the question related to red blood cells which involved aspects of tonicity properties under the concepts of diffusion and osmosis. The report commented that students tend to memorise the concepts of Biology without understanding them. Consequently, it is not surprising that the highest differences between the content knowledge and reasoning among the rural secondary school students in this study 
were found for the items which covered the topic area of passive transport. This strengthens the notion that Malaysian students tend to memorise the concept of passive transport but fail to understand the concept properly.

The findings highlight that it is vital for learners to make sense out of ideas that make up a concept as well as have relevant conceptual knowledge to anchor new ideas to understand the phenomena of diffusion and osmosis from Topic Area 1 to Topic Area 5. Zuckerman (1994) has identified eight inaccurate conceptions about osmosis which are held by high school science students and the study reported that misconceptions about osmosis hindered problem solving of osmosis related questions. Odom (1995) points to the fact that most often teaching focuses not on understanding the concepts of diffusion and osmosis but rather on acquiring facts. Lee and Daniel (2012) highlighted the fact that students' coherent understanding of the whole concept of the cell in the MSPM topic including the concepts of diffusion and osmosis still remains fragmented and the understanding that they have is weakly interrelated. Students' understanding of the phenomena of diffusion and osmosis is a prerequisite for their understanding of certain basic biological functions. This is emphasised by Odom, Barrow, and Romine (2017) who asserted that students' strong understanding of the phenomena of diffusion and osmosis has the potential to promote understanding of basic biological functions.

In sum, although the topic of diffusion and osmosis is claimed to be one of the least difficult topics by some researchers (Çimer, 2012; Mispuah \& Kamisah, 2016), all the students in this study have yet to achieve satisfactory level for scientific knowledge understanding of Topic 3 in the Form Four Biology subject which is MSPM. This is because the percentage of students who selected the desired content knowledge only ranged between $38.6 \%$ to $74.3 \%$. The findings in this study can further provide evidence to support findings of previous studies that students' understanding of these two concepts is still unsatisfactory (Fisher et al., 2011; Oztas, 2014; Oztas \& Oztas, 2016). Additionally, the students in this study has the highest difference between their percentage in scientific knowledge understanding and their percentage of scientific knowledge understanding with correct reasoning for the topic area of passive transport. The following lists the alternative conceptions that have been detected among the rural secondary school Biology students in this study:

1. The concentration of molecules such as polysaccharides and proteins is higher inside the cells than outside the cells when cells are immersed in distilled water. These molecules start moving out of the cell because of the diffusion process but are blocked by cell membranes. Therefore, these 
molecules are rejected by the cell membrane and this causes the cell to become large.

2. The diffusion rate (distance divided by time) is related to cell size. Nutrients are permeable to the plasma membrane and are able to move faster through small cells than larger cells.

3. The mass of the plant tissues does not change when placed in $0.3 \mathrm{M}$ isotonic sugar solution because the water particles inside and outside the cells are the same. Therefore, water movement is not required.

4. The diffusion process and osmosis do not occur in dead cells.

5. The process of deplasmolysis is a process that is the opposite of the plasmolysis process.

As stated by Fisher et al. (2011), typical multiple choice items usually require students to recall specific content while no reasoning is required. This sends the message to students that memorisation of content is important irrespective of understanding. However, this study has shown that the MSPM test (two-tier diagnostic test) appears to provide a feasible approach for evaluating students' understanding of science concepts, and in this case for identifying students' coherent understanding of the concepts of diffusion and osmosis which is in Topic 3 of the Grade 10 Biology subject. Identification of misconceptions about diffusion and osmosis is vital to make meaningful problem solving accessible to more students. Furthermore, identification of misconceptions is needed to develop strategies to provide students with the accurate conceptual knowledge required for scientific problem solving. The focus of this type of instrument is to help the students' reason and to detect common misconceptions among students.

\section{CONCLUSION}

This study focused on the concepts of diffusion and osmosis as both concepts have been observed to be an important process for understanding how the biological system works. Moreover, both concepts have been proven to be difficult to teach in the science class. This is supported by the findings of this study where it was found that the rural school Biology students' understanding of the MSPM topic involving diffusion and osmosis is still unsatisfactory and should therefore be improved further. Various efforts need to be taken to overcome the difficulties faced by students in learning Biology and to make the learning of Biology meaningful. One of the ways in which students can be effectively taught and attain mastery in difficult subjects like Biology is through practical work as students would be 
given the opportunity to experiment and make observations. Hence, in relation to the concepts of diffusion and osmosis, Biology teachers must find ways through practical work to eliminate or prevent misconceptions among students so as to promote meaningful learning of both concepts.

\section{ACKNOWLEDGEMENTS}

The corresponding author presented an oral presentation titled "Understanding of Diffusion and Osmosis among Form Four Rural School Biology Students" in FGMTEK, Izmir, Turkey on 13 April 2019.

\section{REFERENCES}

AlHarbi, N. N. S., Treagust, D. F., Chandrasegaran, A. L., \& Won, M. (2015). Influence of particle theory conceptions on pre-service science teachers' understanding of osmosis and diffusion. Journal of Biological Education, 49(3), 232-245. https:// doi.org/10.1080/00219266.2014.923488

Artun, H., \& Coştu, B. (2011). Unveiling primary student-teachers' misconceptions about diffusion and osmosis. Journal of Turkish Science Education, 8(4), 128-134.

Artun, H., \& Coştu, B. (2013). Effect of the 5E model on prospective teachers' conceptual understanding of diffusion and osmosis: A mixed method approach. Journal of Science Education and Technology, 22(1), 1-10. https://doi.org/10.1007/s10956012-9371-2

Caleon, I. S., \& Subramaniam, R. (2010). Do students know what they know and what they don't know? Using a four-tier diagnostic test to assess the nature of students' alternative conceptions. Research in Science Education, 40(3), 313-337. https:// doi.org/10.1007/s11165-009-9122-4

Chi, M. T. (2009). Common sense conceptions of emergent processes: Why some misconceptions are robust. The Journal of the Learning Sciences, 14(2), 161-199. https://doi.org/10.1207/s15327809j1s1402_1

Çimer, A. (2012). What makes biology learning difficult and effective: Students' views. Educational Research and Reviews, 7(3), 61-71.

Cinici, A., Sozbilir, M., \& Demir, Y. (2011). Effect of cooperative and individual learning activities on students' understanding of diffusion and osmosis. Egitim Arastirmalari-Eurasian Journal of Educational Research, 43(Spring), 19-36.

Curriculum Development Centre. (2006). Integrated curriculum for secondary schools: Curriculum specifications biology form 4. Ministry of Education Malaysia.

Curriculum Development Centre. (2018). Dokumen standard kurikulum dan pentaksiran biologi Form 4. Ministry of Education Malaysia. 
Fisher, K. M., Williams, K. S., \& Lineback, J. E. (2011). Osmosis and diffusion conceptual assessment. CBE-Life Sciences Education, 10(4), 418-429. https://doi. org/10.1187/cbe.11-04-0038

Friedler, Y., Amir, R., \& Tamir, P. (1987). High school students' difficulties in understanding osmosis. International Journal of Science Education, 9(5), 541-551. https://doi. org/10.1080/0950069870090504

Gill, M. K. (2005). Formal reasoning abilities and understanding of diffusion and osmosis among form four biology students. Unpublished Master's thesis, University of Malaya, Kuala Lumpur, Malaysia.

Hasni, A., Roy, P., \& Dumais, N. (2016). The teaching and learning of diffusion and osmosis : What can we learn from analysis of classroom practices? A case study. Eurasia Journal of Mathematics, Science \& Technology Education, 12(6), 15071531.

Johnson, R. B., \& Christense, L. (2017). Educational research: Quantitative, qualitative and mixed approaches (6th ed.). Los Angeles: SAGE Publication.

Lee, S. S. (2013). Mechanistic reasoning of selected Form Four Science on the theory of cell. Unpublished doctoral dissertation, University of Malaya, Kuala Lumpur, Malaysia.

Lee, S. S., \& Daniel, E. G. S. (2012). Development and administration of a two-tier diagnotic test to investigate students' coherent understanding of the movement of substances across the plasma membrane. In Ahmad Nurulazam Md Zain \& D. R. Peter (Eds.), Transforming school science education in the 21st century (pp. 332-345). Penang: SEAMEO-RECSAM Publications.

Lembaga Peperiksaan Malaysia. (2014). Kupasan mutu jawapan biologi 3 SPM 2013. Putrajaya: Kementerian Pendidikan Malaysia.

Lodico, M. G., Spaulding, D. T., \& Voegtle, K. H. (2010). Methods in educational research: From theory to practice (2nd ed.). New York, NY: John Wiley \& Sons.

Maimunah Nasir. (2005). Kefahaman pelajar tingkatan empat tentang konsep-konsep resapan dan osmosis: Satu kajian kes. Unpublished Master's thesis, Universiti Sains Malaysia, Pulau Pinang, Malaysia.

Malińska, L., Rybska, E., Sobieszczuk-Nowicka, E., \& Adamiec, M. (2016). Teaching about water relations in plant cells: An uneasy struggle. CBE-Life Sciences Education, 15(4), ar78. https://doi.org/10.1187/cbe.15-05-0113

Marek, E. (1986). Understandings and misunderstandings of biology concepts. The American Biology Teacher, 48(1), 37-40. https://doi.org/10.2307/4448184

Mispuah Hassan, \& Kamisah Osman. (2016). Pembelajaran biologi berasaskan projek. Bangi: Penerbit Universiti Kebangsaan Malaysia, Selangor, Malaysia.

National Research Council. (2006). America's lab report: Investigations in high school science. Washington, DC: National Academies Press.

Odom, A. L. (1995). Secondary \& college biology students' misconceptions about diffusion \& osmosis. The American Biology Teacher, 409-415. https://doi. org/10.2307/4450030

Odom, A. L., \& Barrow, L. H. (2007). High school biology students' knowledge and certainty about diffusion and osmosis concepts. School Science and Mathematics, 107(3), 94-101. https://doi.org/10.1111/j.1949-8594.2007.tb17775.x 
Odom, A. L., Barrow, L. H., \& Romine, W. L. (2017). Teaching osmosis to biology students. The American Biology Teacher, 79(6), 473-479.

Oztas, F. (2014). How do high school students know diffusion and osmosis? High school students' difficulties in understanding diffusion \& osmosis. ProcediaSocial and Behavioral Sciences, 116, 3679-3682. https://doi.org/10.1016/j. sbspro.2014.01.822

Oztas, F., \& Oztas, H. (2016). How do biology teacher candidates know particulate movements \& random nature of matter and their effects to diffusion? Journal of Education and Practice, 7(29), 189-194.

Patel, A. (2012). Semipermeable membranes, diffusion, and osmosis inquiry: Effective modeling in a high school classroom. Honors College Capstone Experience/ Thesis Projects. Paper 367. http://digitalcommons.wku.edu/stu_hon_theses/367

Stern, J., Ferraro, K., \& Mohnkern, J. (2017). Tools for teaching conceptual understanding: Designing lessons and assessments for deep learning. California: Corwin. https:// doi.org/10.4135/9781506355689

Sweeney, R. M., \& Martin-hansen, L. (2009). Embracing learners' ideas about diffusion and osmosis: A coupled-inquiry approach. Science Scope, 33(1), 38-45.

Taber, K. S. (2011). Models, molecules and misconceptions: A commentary on "secondary school students' misconceptions of covalent bonding". Journal of Turkish Science Education, 8(1), 3-18.

Tekkaya, C. (2003). Remediating high school students' misconceptions concerning diffusion and osmosis through concept mapping and conceptual change text. Research in Science \& Technological Education, 21(1), 5-16. https://doi. org/10.1080/02635140308340

Torkar, G., Veldin, M., Glažar, S. A., \& Podlesek, A. (2018). Why do plants wilt? Investigating students' understanding of water balance in plants with external representations at the macroscopic and submicroscopic levels, Eurasia Journal of Mathematics, Science and Technology Education, 14(6), 2265-2276. https://doi. org/10.29333/ejmste/87119

Tomažič, I., \& Vidic, T. (2012). Future science teachers' understandings of diffusion and osmosis concepts. Journal of Biological Education, 46(2), 66-71. https://doi.org/ 10.1080/00219266.2011.617765

Zuckerman, J. T. (1994). Accurate and inaccurate conceptions about osmosis that accompanied meaningful problem solving. School Science and Mathematics, 94(5), 226-234. https://doi.org/10.1111/j.1949-8594.1994.tb15662.x 